\title{
Ensaio sobre arte e testemunho: Rodrigo Braga e a invenção da experiência
}

\author{
Tania Rivera* \\ Universidade Federal Fluminense, Departamento de Arte. Niterói, RJ, Brasil
}

Resumo: $O$ ensaio enfoca o testemunho como uma posição discursiva e explora seu papel na simbolização do trauma. Considerando-o como transmissão de centelhas do Real, defende que uma de suas modalidades seria a invenção da experiência, tal como aponta parte da produção contemporânea em artes visuais. Para melhor explorar essa hipótese, propõe um diálogo com alguns dos trabalhos apresentados pelo artista brasileiro Rodrigo Braga em sua exposição Mais Força que o Necessário, realizada na Bélgica em 2010.

Palavras-chave: testemunho, trauma, arte contemporânea, psicanálise, invenção da experiência.

\section{Trauma, narração e fantasia}

Dar testemunho é, sobretudo, uma posição discursiva na qual está em jogo uma busca da verdade. Em termos jurídicos, como bem sabemos, as testemunhas são pessoas capazes de colaborar em um julgamento, seja por terem vivido diretamente uma dada situação que podem relatar, seja por trazerem informações que auxiliam de forma colateral no esclarecimento dos fatos. Vê-se, assim, que a posição de enunciação da testemunha costuma implicar uma distância entre o acontecido e o que, a posteriori, dele pode ser dito, e nessa distância insinua-se a possibilidade da mentira, do falso testemunho. Nesse mesmo hiato vem necessariamente alojar-se, também, algum grau de ficcionalização.

Mais do que optar entre realidade e ficção e, no caso de reconhecer à segunda uma primazia, recair em um relativismo estéril que pode abrir as portas a revisionismos hipócritas, parece-me importante ressaltar que todo fato histórico clama pela ficção, na medida exata em que se trata de um fato humano. Um acontecimento jamais se apresenta cruamente, em total independência em relação aos homens que o viveram. $\mathrm{O}$ evento convoca o sujeito a nele se inscrever, e isso só se faz graças a uma produção narrativa que não apenas tem o sujeito como seu enunciador - sujeito gramatical, sujeito da ação ou do estado indicado pelo verbo -, mas também como seu objeto: o relato de fatos vividos versa também, necessariamente, sobre o sujeito, enlaçando-o também como tema, assujeitando-o a um determinado enredo e a uma determinada tessitura de significantes. "Articular historicamente o passado não significa conhecê-lo "como ele de fato foi", como diz Walter Benjamin em uma de suas passagens mais conhecidas. "Significa apropriar-se de uma reminiscência", prossegue ele, "tal como ela relampeja no momento de um perigo" (Benjamin, 1940/1994c, p. 224). Trata-se sempre, no testemunho, de um verdadeiro trabalho de memória.

* Endereço para correspondência: taniarivera@uol.com.br
Na fantasia, produção narrativa que Freud caracteriza como uma atividade psíquica fundamental, o sujeito toma voz e se apropria das circunstâncias de sua vida. Para caracterizar essa atividade, o psicanalista toma como modelo a criação literária e a relaciona ao brincar infantil, em seu conhecido texto Escritores Criativos e Devaneio (Freud, 1907/1976a), que seria mais bem traduzido por "O Poeta e o Fantasiar" ("Der Dichter und das Phatasieren") (Freud, 1907/1955). A fantasia chegou a ser sugestivamente nomeada por ele, em um contexto mais específico, como "romance familiar" (Freud, 1909/1976b), em uma indicação inequívoca de sua estrutura narrativa ficcional. Nessa ficcionalização necessária à própria vida, não se trata exatamente da produção de versões subjetivas que se acrescentam aos fatos, mas sim, mais radicalmente, de apontar que o fato vivido só se torna experiência graças a alguma ficcionalização. O sujeito dele deve se apropriar, tomando-o em narrativas complexas e múltiplas que permanecem em parte implícitas e não correspondem a um enredo simples e fixo.

É importante notar que em tal narrativização não se trata de uma afirmação egoica, ou do que hoje em dia é às vezes chamado "empoderamento". Na fantasia, o sujeito é antes produto do que agente, pois seu poder de criação é pequeno diante dos textos ditos por outros a seu respeito, diante das palavras que usaram para referir-se a ele e para falar com ele, diante das letras escritas em seu corpo ao darem-lhe comida ou the limparem a sujeira (já que todo tratamento do corpo não é feito apenas com o seio ou as mãos, mas sempre com a linguagem). Na fantasia, o sujeito tem que se haver com o lugar que lhe é concedido pelos outros que são fundamentais em sua vida, e deve tratar disso de modo a tomar uma posição sua, apropriando-se do que vem do outro e reafirmando-se como sujeito desejante.

Nesse sentido, podemos dizer que a fantasia tem sempre uma dimensão de testemunho: ela afirma um acontecimento, veiculando e mobilizando a posição do sujeito em uma complexa cena narrativa. $\mathrm{O}$ acontecimento de que se trata é, primordialmente, traumático: ele ecoa aquele evento capaz de nos ferir (trauma, em grego, quer dizer 
ferida) e produzir em nosso corpo a linguagem como cicatriz (naquilo que Freud chama de castração). Tal evento funda o sujeito como assujeitado à ordem simbólica, e ressoa em situações posteriores nas quais esteja em jogo o assujeitamento a outrem em sua face mais violenta - já que "o homem é o lobo do homem", segundo a tradição de Hobbes, à qual se alinha Freud em O Mal-Estar na Cultura (Freud, 1929/2010b, p. 124). Dar testemunho de tal evento é retomar o elã pelo qual o horror - que assinala o registro que Lacan chama de Real - pode dar lugar à reafirmação do humano (como tratamento cultural do lobo, digamos, pelo Simbólico). Tratar o trauma é refazer aquele trabalho que já está em jogo, pelo menos em parte, na fantasia: trabalho simbólico, trabalho humano por excelência, pelo qual a linguagem cicatriza as feridas.

No tratamento do trauma está presente o apelo a uma posição de alteridade radical que seria capaz de garantir a interdição de que o homem seja o lobo do homem e disponha a seu bel-prazer do outro. Essa posição é claramente a do juiz no tribunal, mas ela pode ser ocupada por outras figuras culturais, das quais o analista é provavelmente aquela que mais explicitamente destaca e mantém o lugar da sustentação do simbólico, descartando a face superegoica do julgamento - aquela que aponta para o fato de o punidor poder eventualmente exagerar e tornar-se, ele também, um lobo. $\mathrm{O}$ analista não julga segundo os preceitos morais ou religiosos, mas ele reafirma, em sua presença, atos e falas, uma posição ética indubitável: a aposta na linguagem como compartilhamento e reafirmação, entre os homens, dessa proibição. Talvez a arte seja um domínio cultural que, gozando de alguma liberdade em relação às normas e aos valores morais e políticos, reafirme também, antes de tudo, a aposta no compartilhamento como transformação do traumático em fantasia.

\section{Repetir, recordar, narrar}

É na exata medida em que a fantasia constitui o sujeito graças a uma apropriação do trauma que a ficção deve ser considerada como procedimento inerente a qualquer testemunho. Trata-se não apenas, a meu ver, de uma impossibilidade de se chegar aos fatos como tais, aos fatos em sua crueza (já que o trauma é justamente o que põe o simbólico em xeque), o que nos levaria a ter que suportar alguma ficção, algum desvio em relação à verdade. Trata-se de aceitar a ficção como dispositivo central de tratamento do trauma, pois ela concede ao sujeito uma posição naquela situação que o fere e exclui. Melhor dizendo, a ficção dá lugar ao sujeito, a partir desse evento anônimo - a expressão nos permite ressaltar que é como um lugar, nessa tomada de posição, que o sujeito se constitui.

Diante do trauma impossível de dizer e elaborar, o que se faz é repetir, segundo Freud. A vítima do acidente de trem pode ter pesadelos em que o trauma se repete a cada noite, por exemplo. A teoria freudiana do sonho como realização de desejo pareceria fracassar neste caso. Com a introdução da noção de pulsão de morte, porém, o psicanalista aponta na repetição desprazerosa uma espécie de grau zero do desejo: é encenando ativamente o trauma, em sonho, que o sujeito desejante pode surgir, tornando-se minimamente senhor daquilo que ele viveu em total passividade. A noção de encenação é fundamental para isso. Do trauma em sua crueza é necessário construir uma cena, seja em pesadelos ou no jogo, na brincadeira. A repetição, dolorosa, é uma maneira de "encenar", por em cena (in Szene setzen) o trauma, como o menino que brinca de fazer desaparecer um carretel estaria, segundo o psicanalista, pondo em cena a partida da mãe (Freud, 1920/2010a, p. 173). Tornada jogo e assim repetida, a repetição pode engatar alguma elaboração, alguma transformação da cena, e chega até a produzir prazer, em vez do gozo ligado à mera repetição mortífera.

Poucos anos após essas formulações de Freud, Walter Benjamin mostrou ser dele um discípulo fiel - enquanto boa parte dos psicanalistas da época as rejeitou ou ignorou - ao retomar essas ideias em Brinquedo e Brincadeira. Observações sobre uma Obra Monumental. Segundo ele, no jogo infantil com coisas inanimadas ensaiamos os "ritmos originais" que mais tarde redescobriremos, no amor, ao penetrarmos nos ritmos de um outro ser humano. Mais do que se tratar de mero ensaio para se chegar a outra coisa, o filósofo aponta que "é justamente através desses ritmos que nos tornamos senhores de nós mesmos" (Benjamin, 1928/1994a, p. 252). Tomar a repetição como ritmo é uma bela leitura da questão da pulsão de morte, e Benjamin não deixa de nela ressaltar a violência. Na repetição, não se trata apenas, diz ele, de "assenhorar-se de experiências terríveis e primordiais pelo amortecimento gradual, pela invocação maliciosa, pela paródia", mas "também de saborear repetidamente, do modo mais intenso, as mesmas vitórias e triunfos" (p. 253). O modo pelo qual nos apropriamos da experiência é, ele mesmo, intenso e excessivo, e isso diz respeito não apenas às "vitórias e triunfos", mas também - é inevitável, mesmo que Benjamin nesse ponto pareça curiosamente esquecê-lo aos eventos dolorosos e traumáticos.

É justo nesse momento que o filósofo aplicará a teoria freudiana da repetição do trauma no brincar infantil à questão da narração, o que o próprio psicanalista jamais chegará a fazer explicitamente. "O adulto alivia seu coração do medo e goza duplamente sua felicidade quando narra sua experiência", diz Benjamin (1928/1994a, p. 253). Mas se a "felicidade", "as vitórias e triunfos" são duplicadas pela sua narração, o que dizer das "experiências terríveis e primordiais"? Sem tratar delas explicitamente, Benjamin deixa a brecha para nos perguntarmos se estas últimas não seriam, também, duplicadas - e, portanto, repetidas, em certa medida - no ato de narrá-las. É em uma espécie de nó sintomático, portanto, que aparece uma face insuspeita da narração: a ela está ligada não apenas o amortecimento do trauma, mas também a repetição. Narrar é em alguma medida, assim como o brincar infantil, uma maneira de repetir e gozar duplamente da experiência, trazendo-a à representação, à encenação (Benjamin nota a riqueza semântica 
do termo Spielen, em alemão: jogar, brincar, mas também representar, como no teatro). Devemos concluir disso que a narração pode, portanto, ao menos em parte, servir à compulsão, à repetição. Por um lado, ela serve ao amortecimento e suavização da experiência, à ligação pulsional que mescla Eros a Tânatos, graças à transposição de seus elementos em um outro "palco", uma outra cena: aquela da fantasia. Por outro lado, devemos considerar que ela seria também capaz de convocar o gozo de modo intenso, excessivo, pendendo para o lado da pulsão de morte em uma repetição estéril que impossibilita a transposição e a ligação pulsional. Há algo de terrível no reino da narração.

No horizonte da narração, está presente, assim, a possibilidade de que ela se transforme em repetição mortífera, em reafirmação do sofrimento para além das palavras. Essa parece-me ser uma observação importante e mesmo fundamental para a clínica analítica, na qual por vezes nos deparamos com falas repetidas e repetidoras, nas quais a intervenção do analista vem tentar engatar alguma elaboração. Contudo, não terei aqui espaço para explorar tal ideia. Interessa-me apenas, neste ensaio, apontar que a narração não é, nela mesma, garantia de um trabalho de memória, pois seu motor silencioso é a repetição, com o gozo que esta carrega. A narração pode, assim, silenciosamente, chegar a se desviar de sua tarefa cultural de fazer do trauma linguagem, em uma experiência compartilhada, para reafirmá-lo como repetição anuladora do sujeito. Seja qual for a via que nele prevalecerá - aquela da elaboração ou aquela da repetição -, é importante notar que narrar é um ato que carrega em si a força do trauma.

\section{Trauma e transmissão}

A literatura talvez possa ser definida como uma narrativa capaz de convocar e colocar em primeiro plano a força traumática da narração - mesmo quando o escrito não se apresenta como um testemunho, mesmo quando o texto não tematiza situações de sofrimento extremo. $\mathrm{Na}$ surpreendente e um tanto abrupta citação com que Benjamin fecha o texto Brinquedo e Brincadeira..., tal força traumática mostra sua potência de arrebatamento, uma vez transformada em imagem: "Um poeta contemporâneo disse que para cada homem existe uma imagem que faz o mundo inteiro desaparecer; para quantas pessoas essa imagem não surge de uma velha caixa de brinquedos?" (Benjamin, 1928/1994a, p. 253). Diante de uma imagem poética, o resto do mundo naufragaria. Tal imagem (Bild) vem da infância, de um passado primordial tornado história, e ela carrega para cada um uma singularidade extrema. Um brinquedo é capaz de carregar a memória de um acontecimento terrível, que foi tornado jogo e assim transformado em prazer, nos primórdios de cada vida.

A partir da elaboração do trauma, a fantasia mostra aí sua potência de criar objetos/imagens, e revela a memória como seu mecanismo de funcionamento. De fato, a fantasia é produção narrativa na medida em que ela consiste em uma operação sobre o tempo; como diz Freud, ela parte da irrupção de um desejo atual para ir buscar no passado uma situação de satisfação, e então reportá-la ao futuro "dessa forma o passado, o presente e o futuro são entrelaçados pelo fio do desejo que os une" (Freud, 1907/1976a, p. 153). Para tornar-se literatura, ou seja, ser capaz de atingir o outro, essa singularidade radical, essa memória íntima deve poder se transmitir. Seu caráter pessoal, segundo Freud, geraria apenas repulsa no outro, a não ser que o escritor consiga, em sua ars poetica, "superar esse nosso sentimento de repulsa, sem dúvida ligado às barreiras que separam cada ego dos demais" (p. 158). A transmissão é o que pode, do testemunho, fazer literatura. E talvez ela seja até mesmo capaz de produzir, pela literatura e pela arte, algum legítimo testemunho: compartilhamento das experiências traumáticas e reafirmação coletiva da possibilidade de elaborá-las.

O testemunho como posição discursiva dependeria, assim, não só do lugar e da modalidade de sua enunciação, mas também da efetividade de sua transmissão. Não bastaria que o autor tenha vivido a situação por ele relatada, é preciso que o texto permita que o leitor também a experiencie. Não é o grau de realismo, de crueza ou de fidelidade aos fatos que garantiria tal eficácia. Na verdade, nada a garante. Só se pode dizer que ela aconteceu ou não - dessa transmissão só se pode dar testemunho, por sua vez. Na transmissão, diferentemente da comunicação, a ênfase não está no conteúdo da informação, mas sim em sua força experiencial. E, na experiência, aquilo que se transmite se inflexiona e transforma ao menos um pouco, pois põe em obra o fantasiar do leitor. Como na brincadeira chamada "telefone sem fio", algo se perde, algo se modifica e algo chega às vezes a se inventar. Seja como for, na transmissão o que se passa, mais do que o relato, é a missão (trans-missão) de relatá-lo, por sua vez, a outra pessoa. De passá-lo adiante.

A noção de Real já carrega nela mesma algo que, na experiência, não é exatamente de ninguém - trata-se de uma experiência anônima, mas que é de todos nós. Como diz incidentalmente Lacan (1977), "é muito impertinente que o Real não se conceba senão por ser impróprio" (página). Impertinente e impróprio, o Real não pertence a ninguém, mas nos chama, impróprio, a que dele nos apropriemos. A apropriação deve ser conjugada na primeira pessoa do plural, ela é tarefa coletiva - no sentido indicado pela curiosa observação de Benjamin segundo a qual "também o coletivo é corpóreo” (Benjamin, 1929/1994b, p. 35). Ela nomeia a operação que conjuga o corpo e a linguagem, o singular e o coletivo. A operação pela qual, no fim das contas, a Cultura se define.

Real é aquilo que clama por ser transmitido entre nós.

\section{A Invenção da Experiência}

Desde os anos 1990 fala-se, no campo da Arte Contemporânea, em uma estética do Real baseada na leitura da questão do trauma realizada por Lacan, acentuando-se a repetição como algo diferente de uma reprodução pautada pela representação simbólica. O principal defensor dessa 
noção é o historiador e crítico americano Hal Foster, que em seu O Retorno do Real, publicado em 1996, fala da passagem da "realidade como um efeito da representação para o real como uma coisa de trauma" (Foster, 2014, p. 136). Não cabe aqui um exame mais detido dessa concepção em Foster e em outros autores; quero apenas apontar que essa noção foi muitas vezes tomada como um encorajamento à apresentação mais crua possível do trauma no campo da arte. Parte da produção contemporânea visaria, como diz Foster, "atacar a imagem" e mesmo "romper o anteparo" (p. 136), a tela que permite que uma imagem se faça sobre o buraco do trauma. Quando se trata de colocar-se como testemunho de um trauma vivido pelo artista, tal tendência pareceria acreditar um tanto ingenuamente no poder da apresentação do trauma em si, sem qualquer anteparo ou imagem, ignorando que se lida sempre e necessariamente com um tratamento simbólico do trauma, especialmente naquilo que o habilita a uma transmissão. Tal estratégia de apontamento direto do Real parece-nos muitas vezes votada ao fracasso, justamente ao acreditar em uma apresentação direta do fato, o que pode fixar a experiência no passado e permitir que o espectador (ou leitor), apesar de reconhecer nesse evento o terror, permaneça a uma distância segura em relação a ele.

Pensado sob a chave da transmissão, em contraste, o testemunho pode se potencializar como trabalho atual de memória do próprio espectador/leitor. Isso exige que se assuma o tratamento ficcional do trauma e nele se aposte: é necessário rearranjar os fatos (fazê-los humanos) para que neles possamos nos alojar. O Real repulsa o sujeito - é preciso simbolizá-lo minimamente para que ele possa ser reevocado por imagens capazes de veiculá-lo. Aqui, o terreno é incerto, na medida em que ao desconfiar da possibilidade de apresentar o Real como tal e se aliar ao Imaginário, o artista corre o risco de construir imagens que recobrem o trauma e o mantêm à distância, apaziguando-o sob o modo da mera evitação. Em um agenciamento oposto a esse recobrimento, a arte conta com dispositivos capazes de revirar o Imaginário, dando notícias do Real, como temos insistido com a ideia de um "avesso do Imaginário" (Rivera, 2013). Graças a tal reviramento, sempre endereçado a um outro, torna-se assim possível retomar intimamente aquilo que, estando fora, no outro, mostra-se radicalmente meu - aquilo que é intimamente estranho, a "extimidade", no neologismo de Lacan (1986, p. 167).

$\mathrm{O}$ artista brasileiro Rodrigo Braga foi convidado a passar três meses, em 2010, no In Flanders Fields, museu belga localizado na cidade de Ypres (ou Ieper, em flamengo) e consagrado à memória da Primeira Guerra Mundial, que nessa região de Flandres Ocidental teve batalhas violentíssimas, com enorme número de vítimas militares e civis. É atividade corrente, hoje, a prática desse tipo de "residência artística", na qual um artista é convidado por alguma instituição a passar um tempo em um local diferente de seu habitat e ali gerar trabalhos que serão expostos no final do período. Nesse tipo de proposta, a ênfase recai sobre a vivência de uma determinada realidade - incluindo a interação com outros, evidentemente -, que resulta em uma produção artística capaz de transmiti-la. O campo das residências artísticas põe em primeiro plano, assim, a dimensão experiencial da arte, ressaltando-a sobre o valor do objeto de arte nele mesmo. E ela retoma, desse modo, uma prática comum a poetas e artistas em geral, especialmente a partir do Romantismo: aquela da viagem transformadora de si e de sua arte.

Os trabalhos artísticos apresentados em Ypres na exposição More Force than Necessary, cuja maioria foi pouco vista no Brasil, parecem-me importantes para levar adiante a hipótese de que a transmissão é um ponto principal do testemunho, e que ela pode até prescindir de uma participação factual do transmissor na época do acontecido, consistindo em uma espécie de invenção da experiência. Ao colocar em jogo a História de modo a agenciar nela um lugar para o sujeito, a arte pode ser capaz, como veremos com o trabalho de Braga, de capturar nosso próprio trabalho de memória, nosso "fantasiar", transmitindo-nos algo do trauma, ao mesmo tempo em que o trata simbolicamente.

Rodrigo Braga nasceu em Manaus de pais pernambucanos, que residiam há poucos anos na capital da Amazônia. Viveu em Recife até poucos anos atrás, quando se radicou no Rio de Janeiro. Como a maioria dos brasileiros, ele e sua família tiveram pouca ligação direta com as Grandes Guerras do século passado. A ida a Ypres foi sua primeira residência artística internacional. Ele explorou a região e as marcas que nela deixou a Primeira Guerra, além de ter passado muito tempo mergulhado nos arquivos do Museu In Flanders Fields, auxiliado pela equipe da instituição. Em seguida realizou uma série de ações registradas em vídeos curtos, algumas fotografias e intervenções em objetos e imagens históricas. Tentaremos aqui dialogar com uma parte desses trabalhos.

Nos filmes exibidos nessa exposição, o próprio Rodrigo dá corpo ao "soldado saco de areia", cuja farda ele projetou juntando elementos de uniformes de diferentes nações participantes do conflito, e mandou confeccionar no tecido utilizado nos sacos de areia comumente utilizados nas trincheiras. Capacete, botas e uma espécie de bandagem usada à guisa de meias completam o traje. O filme Casulo mostra duas árvores velhas que se localizam a poucos metros de distância uma da outra e que foram difíceis de encontrar nessa região, na qual quase toda a vegetação foi destruída durante o conflito terminado em 1919. O soldado saco de areia passa ao redor dessas árvores um arame farpado indo do chão até pouco além de sua altura. Com o auxílio de um tronco, salta então para dentro do espaço assim formado e tenta, com certo incômodo, nele descansar. O que fere, o arame farpado, parece poder também servir de abrigo - essa ação apresenta assim, alegoricamente, uma ambiguidade que talvez seja fundamental à questão da violência.

Diferentemente de um ator que se imbuísse do estereótipo do soldado em sua força e coragem, em uma interpretação naturalística, Rodrigo Braga encarna o personagem de um modo muito curioso, sutil e ao mesmo tempo vigoroso. Ele parece muito pouco à vontade. Há algo de incerto e mesmo desengonçado em seus gestos. Sua marcha não é aquela obrigatória nos quartéis, e o mais simples de seus movimentos 
traz sempre o signo de uma desconformidade. Há um hiato entre ele e o papel que se trata de representar, e essa desconexão tem algo de irônico ${ }^{1}$. Há momentos em que isso põe em primeiro plano a ludicidade que o trabalho do ator em geral encobre, e tem-se então a impressão de se estar diante de uma criança que brinca pela primeira vez, desajeitadamente, de ser um soldado em guerra. Em outros momentos, a ação do artista parece mostrar-se mais claramente como uma sátira corrosiva à situação daqueles homens - quase crianças, de fato, no caso de muitos deles - tomados como meros instrumentos de uma absurda máquina de guerra. Cada um daqueles homens do passado não se encaixa bem, como nos faz ver Braga, no papel de "lobo do homem".

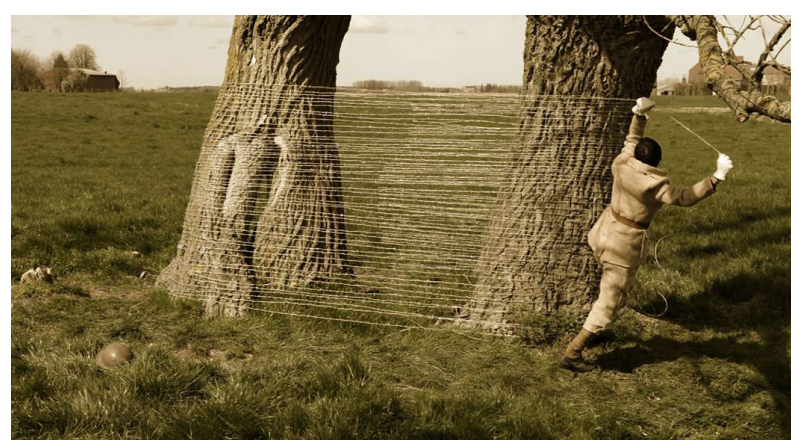

Figura 1. Still de Casulo - Rodrigo Braga, 2010.

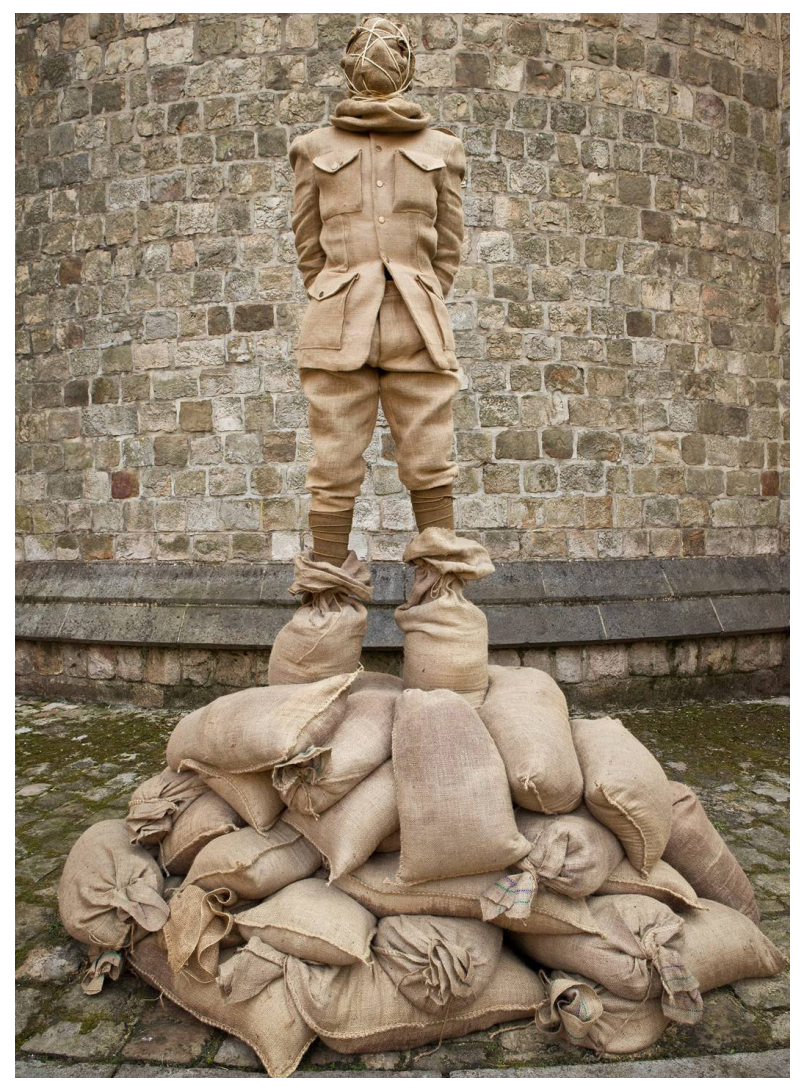

Figura 2. Monumento ao Soldado Saco de Areia - Rodrigo Braga, 2010.

1 Em uma fotografia de 2007 que tem por título Hiato, justamente, Braga realiza uma ironia muito potente. Trata-se de uma cauda de animal cortada.
O próprio mecanismo da representação é assim problematizado, posto em crise e apresentado como tal ao espectador. Não se trata, nisso que revira essa representação em uma apresentação, de o próprio Rodrigo se afirmar e mostrar em sua singularidade, no hiato em relação a seu personagem - trata-se, ao contrário, de agenciar um lugar vago, um lugar no qual qualquer um de nós é convidado a se colocar por um instante: o lugar anônimo do sujeito do trauma. Como diz Walter Benjamin em sua leitura marxista dessa posição, ela implica um risco, um perigo, aquele de "entregar-se às classes dominantes, como seu instrumento" (Benjamin, 1940/1994c, p. 224). Esse soldado não é ele, Rodrigo Braga, mas um soldado anônimo, qualquer soldado ou todos os soldados do mundo. Na fotografia Monumento de Areia, ele tem sua cabeça e pescoço também cobertos por sacos de areia vazios, de modo que nenhuma parte de sua pele fica à mostra. Seus pés estão fincados em sacos cheios de areia, sobre algumas dezenas de sacos de areia formando um curioso pedestal. Sua postura é aquela de um soldado no momento em que vai ser executado, mas toda a montagem remete a uma estátua monumental (monumento a quê? À areia, ao absurdo da guerra?). Esse soldado somos nós.

Estórias do Soldado Saco de Areia, o filme mais longo da série, é uma montagem de diferentes ações que se repetem muitas vezes. Devidamente paramentado com arma, munição e cantil, o personagem sobe alguns degraus, dá meia-volta e desce, sempre um pouco hesitante, como se não soubesse bem o que fazer ou para onde ir. Em outra ação, ele tem uma tigela na mão, olha para seu interior e dá meia-volta, marchando para receber de uma mão anônima algum alimento inexistente; dá alguns passos, olha para a tigela e recomeça. Ele tenta chegar correndo ao topo de um pequeno monte de terra solta, mas desliza e cai rolando a cada tentativa. Seu rosto aparece repetidamente através do vidro quebrado de uma janela alta, graças à ação repetida de saltar de dentro do edifício. No solo cinzento da região, joga a uma pequena distância uma pedra um pouco maior do que sua mão, em seguida pega-a do chão e volta a jogá-la alguns passos à frente de si. Ele cava com uma picareta um buraco na terra, como quem cava talvez uma trincheira, avançando aos poucos, para por fim deitar-se de bruços nessa fenda na terra e nela desaparecer. Além da desconformidade que o personagem apresenta em relação à situação encenada, a repetição aparece como elemento fundamental nessas ações e na maneira como são editadas. A repetição é também ressaltada pelo enquadramento fixo de cada ação. O próprio artista, sozinho, se ocupa da câmera, delimitando a priori o campo de seus gestos, e a escolha do quadro fixo acentua o dispositivo pelo qual a representação é assumida como tal, sem recurso à naturalização que poderia ser alcançada pelo uso de mais de uma câmera e de uma edição que integrasse diferentes pontos de vista.

A trilha sonora de Estórias do Soldado Saco de Areia acompanha magistralmente a reiteração, o esforço e o fracasso das ações apresentadas: trata-se de uma aula de música. Rodrigo Braga localizou em suas pesquisas 
algumas das peças para trompete usadas pelos militares na época da Primeira Guerra, e pediu a um professor que as ensinasse a seus alunos. Os temas marciais aparecem, assim, fragmentada e repetidamente, alternados por falas do professor, que às vezes cantarola algum trecho à guisa de demonstração didática. De fato, todas as ações apresentadas têm algo de um ensaio, de uma tentativa um pouco tosca de representar algo.

Como já era o caso em trabalhos anteriores do artista, a repetição está ligada a um dispêndio exagerado: as ações devem ser realizadas até a exaustão (ou quase). Como indica o título da exposição, trata-se de empregar Mais Força do que Necessário. Essa condição traumática do exagero é retomada e assumida pelo próprio trabalho, sob o modo da repetição. Além da desconformidade irônica ou satírica, o modus operandi aqui é aquele do "desassossego" (para usar o termo que Braga usa em uma série de 2004, Risco de Desassossego), que impele à ação inútil, sempre repetida, exageradamente retomada. O exagero e a força desmedida aparecem mais espetacularmente nas fotografias Mais do que o Necessário I e II, nas quais a parte superior do corpo do artista aparece banhada com seu próprio sangue, e sua cabeça apoia-se contra o tronco de uma árvore (no primeiro trabalho) ou contra uma pedra (no segundo). Apesar da dramaticidade dessas imagens, nelas a pose do artista é precisa, controlada. Não se trata da simulação de um acidente, mas da apresentação da ferida de modo metafórico (na guerra, talvez a humanidade bata a cabeça contra tudo e todos, em uma teimosia mortífera). A árvore e a pedra estão salpicadas de sangue, e toda a natureza (ou todo o mundo) participa, assim, desse instante de rememoração e disseminação de um acontecimento terrível.

Tal disseminação parece-me fundamental no trabalho desse artista. Rodrigo Braga afirma que "o lugar" o "chama" (em comunicação pessoal, março de 2014). O homem - em sua ferida - dissemina-se no mundo, no chão, na terra, como em outra fotografia, Carne e Pele, que mostra a farda do soldado saco de areia semienterrada aos pés de uma árvore, tendo o volume ausente do corpo do soldado ocupado pela terra negra e suas folhas secas. Referindo-se a outros de seus trabalhos, o artista afirma: "Ligo arte e natureza". Tal continuidade do homem com o mundo parece-me fundamental como uma retomada do que no trauma aparece como uma espécie de confusão com o acontecimento: ainda não há um eu bem delimitado, portanto corremos o risco de, sob a égide da Pulsão de Morte, nos dissolvermos nos elementos do mundo, voltando, como diz Freud (1920/2010a), "ao estado inorgânico" (p. 204). A obra de Braga ensina que, para repetir tal condição na tentativa de simbolizar o trauma, é necessário retomar a dissolução pela qual estamos assujeitados à situação traumática, para dela fazer uma ativa disseminação do sujeito no mundo: operação pela qual elementos do mundo tornam-se capazes de carregar e transmitir algo do sujeito. Na arte, talvez os objetos tomem uma estranha capacidade de memória e testemunho, carregando - como as relíquias - algo de fundamental ao homem.

Como em Mais do que o Necessário I e II, a ação que se desenrola no filme Fronte é dramática, porém contida. O soldado saco de areia está de frente para a cabeça de um manequim que porta uma farda militar. A câmera enquadra os dois rostos de perfil, em simetria quase perfeita. Durante pouco mais de três minutos, Rodrigo encara esse "inimigo", tentando sentir raiva dele. Desde os instantes iniciais desse belo trabalho, trata-se de sofrimento, em uma autenticidade vigorosa e difícil de localizar. No semblante do artista encena-se algo fundamental, difícil de pôr em palavras, na relação com o outro. Terror e compaixão, semelhança e diferença entram em jogo como se estivessem irresistivelmente tomados por uma armadilha simbólico-imaginária construída por esse artista (que assim mostra-se um tanto soldado, em seus ardis para capturar o outro, o inimigo). $\mathrm{Na}$ força dessa encenação, algo clama desde o passado e nos solicita elaboração, ou mesmo redenção. Nela está em primeiro plano um índice misterioso, que talvez seja aquele a que se refere Benjamin (1940/1994c) ao afirmar que "o passado traz consigo um índice misterioso, que o impele à redenção" (p. 223).

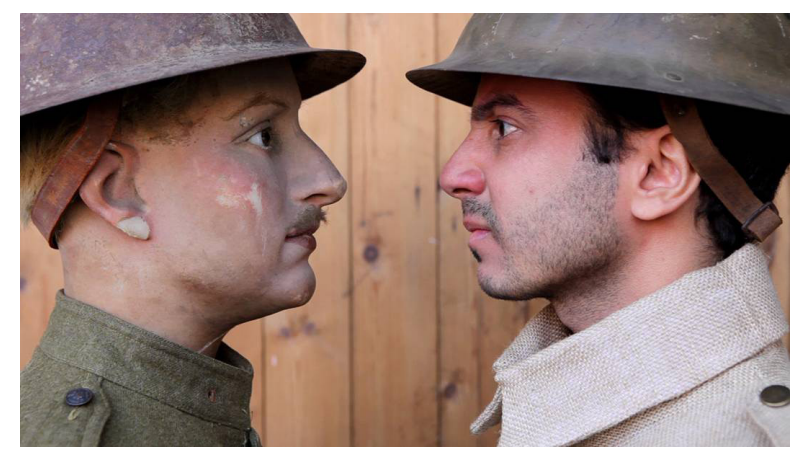

Figura 3. Still de Fronte - Rodrigo Braga, 2010.

Uma das ações que compõem Estórias do Soldado Saco de Areia e que ainda não mencionei apresenta uma imagem imóvel: um corpo jaz sob um tecido branco, ao lado de um muro antigo. Ela se repete, terrível, alternando-se com imagens das demais ações do filme, até reaparecer em o plano final: subitamente, o corpo se mexe e ajeita tranquilamente sua posição, como se estivesse simplesmente dormindo. Vitória do jogo, do trabalho artístico sobre a morte e o terror.

Apropriando-se das pequenas centelhas que nos atingem através da História, tornando nossas as pequenas histórias - as histórias dos pequenos personagens, sempre vencidos, nunca vencedores de nenhuma guerra de modo a agenciar pequenas ficções, pequenas subversões, a arte retoma o trauma e o atravessa, reafirmando o que há de humano no terror e na violência extremas. O trabalho artístico talvez tenha sutilmente, como diz Benjamin (1940/1994c) do historiador, "o dom de despertar no passado as centelhas da esperança" (p. 224). 




Figura 4. Coletânea de stills de Fronte - Rodrigo Braga, 2010.

\section{Essay on art and testimony: Rodrigo Braga and the invention of experience}

Abstract: The essay focuses testimony as a discursive position and explores its role in the symbolization of trauma. Conceiving it as a transmission of sparks of the Real, we argue that one of testimony's modalities can consist in an invention of the experience, as some contemporary visual art works seem to propose. To explore this hypothesis, we discuss some of the works shown in Belgium in 2010 by Brazilian artist Rodrigo Braga in the exhibition More Force than Necessary.

Keywords: testimony, trauma, contemporary art, psychoanalysis, invention of the experience.

\section{Essai sur l'art et le témoignage: Rodrigo Braga et l'invention de l'expérience}

Resumé: Cet essai comprend le témoignage en tant que position discursive et explore son rôle dans la symbolisation du traumatisme. En réfléchissant sur le témoignage comme transmission d'étincelles du Réel, il soutient qu'une de ses modalités peut être celle de l'invention de l'expérience, comme le montre une partie de la production contemporaine en arts visuels. Pour développer cette hypothèse, il propose un dialogue avec quelques-uns des travaux presentés par l'artiste brésilien Rodrigo Braga en Belgique en 2010, dans l'exposition Plus de Force que le Nécessaire.

Mots-clés: témoignage, traumatisme, art contemporain, psychanalyse, invention de l'expérience.

\section{Ensayo sobre arte y testimonio: Rodrigo Braga y la invención de la experiencia}

Resumen: Este ensayo comprende el testimonio como una posición discursiva y explora su papel en la simbolización del trauma. Considerando el testimonio como transmisión de centellas del Real, defiende que una de sus modalidades sería la invención de la experiencia, como lo muestra parte de la producción contemporánea en artes visuales. Para mejor explorar esta hipótesis, se propone un diálogo con algunos de los trabajos presentados por el artista brasileño Rodrigo Braga en su exposición Mais Força que o Necessário [Más Fuerza que el Necesario], realizada en Bélgica en 2010.

Palabras clave: testimonio, trauma, arte contemporáneo, psicoanálisis, invención de la experiencia.

\section{Referências}

Benjamin, W. (1994a). Brinquedo e brincadeira. Observações sobre uma Obra Monumental. In W. Benjamin, Obras escolhidas. magia e técnica, arte e politica: ensaios sobre literatura e história da cultura (pp. 249-253). São Paulo, SP: Brasiliense. (Texto original publicado em 1928)

Benjamin, W. (1994b). O surrealismo. Último instantâneo da inteligência europeia. In W. Benjamin, Obras escolhidas. Magia e técnica, arte e política: ensaios sobre literatura e história da cultura (pp. 21-35). São Paulo, SP: Brasiliense. (Texto original publicado em 1929)

Benjamin, W. (1994c). Sobre o conceito de história. In W. Benjamin, Obras escolhidas. magia e técnica, arte e politica: ensaios sobre literatura e história da cultura (pp. 222-232). São Paulo, SP: Brasiliense. (Texto original publicado em 1940)

Foster, H. (2014). O retorno do real. São Paulo, SP: Cosac Naify. 
Freud, S. (1955). Der Dichter und das Phantasieren. In S. Freud, Gesammelte Werke (Vol. 7, pp. 213-223). Londres: Imago. (Texto original publicado em 1907)

Freud, S. (1976a). Escritores criativos e devaneio. In S. Freud, edição standard brasileira das obras psicológicas completas de Sigmund Freud (J. Salomão, trad., Vol. 13, pp. 149-158). Rio de Janeiro, RJ: Imago. (Texto original publicado em 1907)

Freud, S. (1976b). Romances familiares. In S. Freud, Edição standard brasileira das obras psicológicas completas de Sigmund Freud (J. Salomão, trad., Vol. 9, pp. 243-247). Rio de Janeiro, RJ: Imago. (Texto original publicado em 1909)

Freud, S. (2010a). Além do princípio do prazer. In S. Freud, Obras completas (P. C. de Souza, trad., Vol. 14, pp.
161-239). São Paulo, SP: Companhia das Letras. (Texto original publicado em 1920)

Freud, S. (2010b). O mal-estar na cultura. Porto Alegre, RS: L\&PM. (Texto original publicado em 1929)

Lacan, J. (1977). L'insu que sait de l'une-bévue s'aile à mourre (Seminário 1976-1977). Inédito. 8 mars 1977.

Lacan, J. (1986). Le Séminaire. Livre VII. La Sublimation. Paris: Seuil.

Rivera, T. (2013). O avesso do imaginário. Arte contemporânea e psicanálise. São Paulo, SP: Cosac Naify.

Recebido: 21/04/2014

Revisado: 09/06/2014

Aceito: 28/06/2014 